\title{
The Replacement of Other Cases with the Nominative and Accusative: Examples from the Epigraphic Corpus of Lusitania
}

Silvia Tantimonaco

(University of Barcelona)

\begin{abstract}
In Vulgar Latin, the nominative and the accusative are used as neutral forms of nouns to replace the oblique cases, whose meaning and functions they can duly acquire. In this paper, I analyse the examples of such uses in the epigraphic corpus of early and late Lusitania, with special attention to the development of the Ibero-Romance system.
\end{abstract}

\section{Keywords}

Vulgar Latin; nominative; accusative; syntax; Hispanic Latin; Lusitania

This paper was prepared within the framework of the projects 'Escritura, cultura y sociedad en el conuentus Scallabitanus' (FFI2015-68571-P), 'Computerized Historical Linguistic Database of Latin Inscriptions of the Imperial Age' (NKFIH No. K 108399 and K 124170) and 'Lendület ('Momentum') Research Group for Computational Latin Dialectology' (Research Institute for Linguistics of the Hungarian Academy of Sciences). I would like to thank Béla Adamik and Daniela Urbanová for their useful suggestions as well as Zsuzsanna Sarkadi and Jonathan Griffiths for their linguistic assistance. 


\section{Introduction}

In Vulgar Latin, the nominative and the accusative alternate as neutral forms, ${ }^{1}$ replacing other cases that would be required from the logical structure of the syntactical expression at hand. Such situations can produce a loss of agreement between two or more terms of a sentence and anomalies in the government of cases. ${ }^{2}$

As an unmarked case, the nominative is semantically void and syntactically independent from the rest of the sentence. ${ }^{3}$ Thus, it is able practically to replace any other case of the system without altering the meaning of the sentence. ${ }^{4}$ Similarly, the accusative can acquire a different meaning according to the context, for it does not contain any semantic value neither. ${ }^{5}$ However, unlike the nominative, the accusative bears a morphological mark indicating its syntactic dependence with another element of the sentence or clause (generally, a transitive verb). It is for this reason that hanging accusatives entail a problem of syntactic harmony (anacoluthon). ${ }^{6}$

Several reasons can explain syntactic mistakes in inscriptions, including contamination among different formulas, ${ }^{7}$ the writer's insufficient level of literacy or his lack of a strong command of Latin, in particular in the case of the inflection of foreign names. ${ }^{8}$ Adams speaks of 'unconstrued nominatives': "the writers, as imperfect learners of Latin, were constantly lapsing into the "unflected" base-form of nouns, presumably the form which they had learnt first'. ${ }^{10}$ Certain asyntactic uses of the nominative are attested even in literature, ${ }^{11}$ but some of them are a clear imitation of the substandard language. ${ }^{12}$

Extralinguistic factors, such as the writer's loss of concentration, material difficulties in engraving an inscription, etc., ${ }^{13}$ can be evoked to explain such errors as well.

1 Hofmann \& Szantyr (1965: pp. 28-30); Bassols de Climent (1992 ${ }^{10}$ : p. 41).

2 Herman (1990 [1966]: pp. 321-322). See also Galdi (2004: pp. 384-408).

3 Moralejo (1986: p. 307); Suárez Martínez (1994a: pp. 115, 117-118 and 123); Id. (1998: p. 783).

4 Suárez Martínez (1994a: p. 117).

5 Moralejo (1986: p. 297).

6 Suárez Martínez (1998: p. 787).

7 Galdi (2004: p. 386).

8 Adams (2013: p. 210).

9 Adams (2013: p. 236). See also Hofmann \& Szantyr (1965: p. 28).

10 Adams (2013: p. 236). See also Hofmann \& Szantyr (1965: p. 27), who quote: App. Prob. 134: Vico capitis Africae, non uico caput Africae.

11 E.g. the so-called 'descriptive' and 'narrative' nominatives (some examples of which are given in Suárez Martínez 1998: p. 784).

12 E.g. the so-called nominatiuus pendens (or 'emphatic nominative', also labelled as 'focal nominative heading' by Adams 2013: p. 215), a hanging nominative placed at the beginning of a sentence and generally picked up by an anaphoric pronoun. On this, see Hofmann \& Szantyr (1965: p. 29), Bassols de Climent (1992 ${ }^{10}$ : p. 25), Suárez Martínez (1994a: pp. 116 and 121) and Id. (1999: p. 782), with examples. This type of nominative is also attested in the tabellae defixiones, see Urbanová (f.c.). A similar construction is the so-called 'thematic nominative' ('thematischer Nominativ'), on which see Hofmann \& Szantyr (1965: pp. 28-29).

13 On this subject, see Marchesini (2004: pp. 200-205). 
Sometimes, syntactic anomalies are hardly discernible from the morpho-phonological processes that occur in Vulgar Latin.

For these reasons, it seems necessary to evaluate each case individually. ${ }^{14}$ In the present paper, I will discuss relevant examples of nominative and accusative forms used in clear disregard of the syntax as found in the epigraphic corpus of Lusitania. ${ }^{15}$

\section{Nominative}

\subsection{Mistakes in Agreement}

The most common situation reflecting a loss of agreement is the interchange between nominative and dative forms. ${ }^{16}$ Funerary, votive, and honorific dedications seem to be particularly sensitive to dative $\sim$ nominative merges, because both constructions, with either the nominative or the dative, were traditionally accepted in epigraphy. ${ }^{17}$

A contamination of these formulas might be explainable owing to the distance between the personal name and the term of endearment in the inscription IRCPacen 52 (= LLDB-32090): D(is) [M(anibus)] s(acrum) / P[R]O[T]YPVS / ux(it) (!) anis (!) [LX?] / mens(ibus) VII d(iebus) V/III h(ic) s(itus) e(st) s(it) t(ibi) t(erra) l(euis) / MERENTIS/SIM/O; however, it is also possible that a term such as patri is missing at the end. ${ }^{18}$ In the inscription CivIgaed 172 (= LLDB-32226), the abnormal genitive / dative form of the term delicatae might be the result of a morphological attraction of the genitive ending in -ae placed just before it: QVINTILLA an(norum) III / M(arci) Curi Quintionis et / Curiae Primulae DELICATAE / $h(i c) s($ ita $) e(s t) s($ it) $t$ (ibi) t(erra) l(euis). The loss of final -s, a typical Vulgar Latin phenomenon depending on the phonological context, ${ }^{19}$ also cannot be excluded in examples where a dative form ending in $-i$ appears instead of a nominative, such as in CIL II, 768 (= LLDB-15335): LONGINVS / Camali (filius) / CAVRIESI (!) / h(ic) s(itus) e(st); or CILCaceres I, 155 (= LLDB-44206): BOVTI/A Latro/ni f(ilia) / HISTIN/IENSI // hic s(ita) / es (!).

14 Cf. Adams (2013: p. 210): 'Material of this type cannot be reduced to a single explanation'.

15 I will provide the text of each discussed inscription or a relevant part of it, together with a bibliographical reference as well as the number of record of the Computerized Historical Linguistic Database of Latin Inscriptions of the Imperial Age (lldb.elte.hu). The abbreviation list concerning the bibliography can be found in LLDB web page.

16 See e.g. Poukens (1912: pp. 36-37), Galdi (2004: pp. 384-392) and Beu-Dachin (2014: p. 188).

17 The nominative construction is supposed to be the original one in dedications, while the dative might be a later development. See Batlle Huguet (1963: p. 67).

18 Some scholars have claimed the existence of a unique case ending -o for the nominative and accusative singular of the second declension, derived from the fluctuation of final $-m /-s$ and from the vocalic merge $o$ $u$. However, this is a very thorny issue that would deserve specific treatment. On this subject, see Gaeng (1977: pp. 76-77 and 99-101), Id. (1984: pp. 38-39), and Id. (1990: pp. 116-118); with specific reference to Hispanic inscriptions, see Carnoy (1906²: pp. 186-199) and Gaeng (1977: p. 60).

See Adamik (2017). 
As for the unexpected shifts from the dative into the nominative, an occasional 'distention' of the syntactical structure of the phrase, because of stylistic or sociolinguistic reasons, is generally admitted..$^{20}$ Indeed, the use of the nominative as a 'neutral case' is particularly frequent in compound phrases combining personal names with attributes or appositions..$^{21}$

It is common that personal names that appear first are correctly inflected, while appositions are left in the nominative, such as in IRCPacen 186a (= LLDB-17383): [L(ucio)?] IVNIO L(uci) f(ilio) Gal(eria) / [P]HILONI IIuir(o) / ex d(ecreto) d(ecurionum) / [FL]AMEN diui August [i] / [p]erpet[uus? - - - Duroniu[s] / [---]f(ilius) Gal(eria) Modestus (fecit). ${ }^{22}$ In other cases, the uninflected term is an attribute, such as in CIL II, 551 (= LLDB-35104): $D($ is) $M$ (anibus) s(acrum) / Docquiricus Vita/lio ann(orum) LXV h(ic) s(itus) e(st) s(it) t(ibi) t(erra) l(euis) / Albania Sabina MA/RITO OBSEQVENTISSI/MO et amicis DVLCIS/SIMVS cum quo uicsi (!)...; or in CILCaceres IV, 1159 (= LLDB-60213): [D(omino) N(ostro) I]mp(eratori) Fl[a(uio)] / [I]VLIO Costa[nt]i[o] (!) / [MAX]IMO TRIVNF/ATOR (!) [m]/axi(mo) s[e]nper (!) $A[u] /[g] u s(t o) b($ ono $) r(e i) p(u b l i c a e)$ [n(ato)]. As Adams observes, 'it might be suggested that in compound phrases, (...) writers did not feel the need to inflect all the elements'. ${ }^{23}$ Indeed the syntactic information is provided only once in the syntagma throughout the mark of the dative, and then it is only implied. ${ }^{24}$ This phenomenon seems to reflect a concern about 'linguistic economy', whereby the speaker (or writer) leaves out part of the syntactic information without weakening the meaning of the message.

Names often acquire a special status in the language, and this can be a reason for their asyntactic use in the nominative, which was felt to be the 'proper' form of the name..$^{25}$ Sometimes the case confusion occurs within a series of proper names, and we can assume that the elements preserved in the nominative represent the names by which the individuals were commonly known, such as in IRCPacen 597 (= LLDB-17579): $\operatorname{Sex}(t o)$ Soio / Quartioni et / CATINIAE / MAXSVMA (!) / Albanus f(ilius) p(onendum) c(urauit); or in CILCaceres III, 1140 (= LLDB-15590): SEPRONIAE (!) [F]irmi / f(iliae) PATERNA Clun(iensi) / an(norum) VI h(ic) s(ita) e(st) dicroco (!) / frater lens (!) s(it) t(ibi) t(erra) l(euis). This phenomenon is attested in the lists of names of the emperors as well, such as in HEp 7, 1273 (= LLDB-59338): [I]mp(erator) Ca(esar) / diui f(ilius) / Parthic(i) / Nerua (!) ne(pos) / TRAIANVS / HADRIANO / Aug(ustus) / pot(ifex) (!) max(imus) / tribunici(a potestate) $V / c o(n) s(u l)$ III refecit / m(ilia passuum) XVIII.

20 Moralejo (1986: p. 308). See also Bassols de Climent (1992 ${ }^{10}$ : pp. 25 and 41).

21 Adams (2013: pp. 216-217).

22 Duouir(o) is a common abbreviation in inscriptions. See e.g.: AE 1980, 265; 1988, 444; CIL II, 3623; 3662; $\mathrm{II}^{2} / 5,85$ and 91 .

23 Adams (2013: p. 210).

24 Suárez Martínez (1994a: pp. 120-121): ‘En los usos llamados apositivo (CIL VIII, 201574: Veneri sancta dea Quintus Gemellinus... uotum soluit) y enumerativo (CIL VI, 10052: uicit Scorpius equis his: Pegasus, Elatres, Andraemo, Cotynus) (...) se puede explicar paradigmáticamente la presencia del nominativo como un uso neutro, en cuanto que término no marcado, por el caso caracterizado correspondiente: las marcas sintácticas vienen señaladas de antemano, por lo que el nombre en aposición queda afectado por ellas y se libera de las propias'.

Adams (2013: pp. 211-213 and 214). For this feature in curse texts, see Urbanová (f.c.). 
Another interesting example is CILCaceres I, 34 (= LLDB-30983): DOMINA / Turibri(gensi) / ATTAEG[I]/NAE (!) s(anctae) / L(ucius) Pontius / Seurinus (!) / pro patr/ em (!) uot/[um - - - . In this case, the nominative/vocative (or even ablative) form domina might correspond to the common epithet by which people invoked the goddess Ataecina, whose cult was widespread in the province of Cáceres. Indeed, according to Adams, 'names (...) are sometimes fossilized in a case that is often used'. ${ }^{26}$

\subsection{Ungoverned Nominatives}

\subsubsection{Nominatiuus pro genetiuo}

Among the anomalies in the government of cases which are attested in Lusitania are a couple of examples of nominatives replacing genitives. Both cases might be described as examples of unconstrued nominatives: NERVA NE(POS) for Neruae nepos, which appears in the above-quoted inscription HEp 7, 1273 (= LLDB-44080); ${ }^{27}$ and CILCaceres II, 688 (= LLDB-70892): Memor/ia (!) Atani / Clauici / Amonici / FRATRES / Tancin/us Cauci/ri (filius) de suo / c(arissimis) f(aciendum) c(urauit) for Memoriae (siue memoriam) Atani Clauici Amonici fratrum Tancinus (...) faciendum (siue faciendam) curauit.

\subsubsection{Nominatiuus pro datiuo}

Beside the examples discussed above, other abnormal uses of the nominative in place of the dative are attested in Lusitania, in contrast with regular government of cases.

The inscription IRCPacen 430 (= LLDB-16400) bears the following text: $D($ is) M(anibus) $s($ a)c(rum) / Maria Euprepi/a QVAI Fate (!) / concesseru/nt uiuere a/nis (!) / XXXXV..., where the relative pronoun $Q V A I$-archaising form of the nominative singular quae-is substituted in for the dative $c u i$, probably with the aim of simplifying the syntactic structure of the phrase. ${ }^{28}$

In some votive texts, the reason for the anomaly seems to lie in the special character of the names, especially when used for divinities or quasi-divinities, such as in Conimbri 11 (= LLDB-28865): LARES Lubanc(os) / Douilonicor(um) / horum Albuiu (!) / Camal(i) f(ilius) sacr(um), where the nominative/accusative/vocative form LARES is used in place of Laribus. Moreover, in both CILCaceres II, 495 (= LLDB-46313): $\mathrm{O}^{+} /$[- - - $\mathrm{An} / \mathrm{radr}$ / atus / BELONA (!) / uotum / aram / [a(nimo) l(ibens) p(osuit)], and CILCaceres II, 631 (LLDB-25562): Saturni/nus To/nci BELL/ONA / a(nimo) l(ibens) p(osuit), the nominative /

26 Adams (2013: p. 211).

27 See above, 2.1.

28 On the other hand, it cannot be excluded that in this phrase QVAI is meant as the dative form of the relative pronoun, showing the evanescence of the pronominal declension (see e.g. CIL XII, $2487=$ LLDB4124: CVI for cuius). 
vocative (or even ablative) form BELLONA appears instead of Bellonae, which would be required stricto sensu.

It is possible that the nominative is also substituted in for the regular dative case in the already quoted inscription CILCaceres II, 688 (= LLDB-15484), where MEMORIA might stand for memoriae - a typical dative-form funerary formula ${ }^{29}$ - or, alternatively, for memoriam - which would be an accusative depending on faciendam curauit..$^{30}$ Nevertheless, it is also possible that, in this case, the nominative memoria absolved the function of referring to object on which the inscription was made. ${ }^{31}$

\subsubsection{Nominatiuus pro accusatiuo}

It is very common that nominative forms ending in - $a$ replace the accusative singular of nouns from the first declension. A typical example in votive texts is ARA for aram depending on a verb such as posuit, fecit, and others (e.g. CIL II, $677=$ LLDB-15483). The same phenomenon is widely reported in other territories of the Roman Empire, and seems to spread from the conjuncture of specific morpho-phonological phenomena which are common in Vulgar Latin, such as the dropping of final -m, the mark of the accusative singular, and consequently the homonymity between the nominative (and vocative) singular ending $-\breve{a}$ and the ablative singular ending $-\bar{a}$, due to the collapse over time of the vocalic quantity. ${ }^{32}$ Consequently, the extended misspelling $-A$ for -am seems to represent 'merely a vulgarism of writing, ${ }^{33}$ while, from the point of view of morpho-syntactic change, it is insecure evidence. ${ }^{34}$

In this regard, the extreme rarity of similar instances in the masculine, at least in Lusitania, seems to be significant. On the inscription ERBeira 206 (= LLDB-36789), which is dated to the first half of the $1^{\text {st }}$ century A.D., we read: [In honorem?] / Bouti[o] / Petobi [f(ilio)] / CIPVS (!) / uiuo (!) / Maelo / Cili f(ilius) / donau(it) / et p(ecunia) s(ua) $f(e c i t)$, where we would expect to find cippum as the direct object of the verbs donauit and fecit. It is possible that the term cippus, as referring to an inanimate object, was treated as a neuter substantive on the analogy with some other words of the second declension, such as uirus or uulgus.

Sometimes the nominative appears instead of the accusative in the so-called 'nomenconstruction', ${ }^{35}$ such as in CIPTP 111 (= LLDB-29960), where we find: VENANTIA NOMEN (...) GESI (!). The origin of such contaminations seems to be the so-called 'metalinguistic nominative', i.e. where the nominative is used to express a name, which is also attested in literature. ${ }^{36}$ However, as I have said, in the case of feminine names we cannot

29 See e.g.: AE 1928, 99; 1936, 65; 2008, 237.

30 See above, 2.2.1.

31 See above, n. 11.

32 Gaeng (1984: p. 17); Id. (1990: p. 113).

33 Adams (2013: p. 132).

34 Adams (2013: p. 248).

35 Adams (2013: p. 221).

36 Hofmann \& Szantyr (1965: p. 27); Adams (2013: p. 221). See e.g. Ov. Met. 1, 169: (Via).. Lactea nomen habet; 15, 96: At uetus illa aetas, cui fecimus aurea nomen. See also Martin (1909: p. 14). 
exclude the possibility of the loss of the accusative's final $-m$, or even that vocatives/ablatives, not nominatives, have replaced the regular accusative forms.

\subsubsection{Nominatiuus pro uocatiuo}

It is not surprising that the nominative, as a neutral case, alternates with the vocative, which is completely asyntactical. Some examples of this phenomenon are attested even in literature. ${ }^{37}$ In Lusitania, there is an interesting text dated to the age of Trajan, Conimbri 357b (= LLDB-28858), which was traced on the wet clay of a shingle: DVATIVS / tacim (!) / fiuliu (!) fe/la (!) te for Duatī taceam filius fellat te. ${ }^{38}$

\subsubsection{Nominatiuus pro ablatiuo}

Particularly in Late Latin, the nominative - as well as the accusative - can replace the ablative in absolute constructions. One example of this phenomenon appears in the inscription ERAEmerita 82 (= LLDB-32297), an official text dated to the years 337-340 A.D.: ... adque ita insistente u(iro) p(erfectissimo) Iulio Saturnino p(raeside) p(rouinciae) L(usitaniae) ITA CONPETENTER / RESTITVTA EIVS FACIES spendidissimae coloniae Emeriten/ sium quam maximam tribuit uoluptatem.

Besides absolute constructions, the nominative appears instead of the ablative in name-expressions such as in CICMerida 20 (= LLDB-32788): Mulier anorum (!) uiginti et / octo perit (!) a partu (!) COGNOMEN / AVRELIA LICINIA FLORIDA rec/cessit (!) de seculo (!) in nomin (e) Cr(isti) (!) / Cristi (!) fedelis (!) in Chr(isto) hoc (!) felix, where we would expect to read mulier... cognomine Aurelia Licinia Florida. The influence of the metalinguistic nominative seems to be probable.

\subsubsection{Praepositio cum nominatiuo pro praepositione cum accusatiuo / ablatiuo}

The nominative can occur after a preposition and replace the regular accusative or ablative, depending on the meagreness of linguistic resources or on an occasional lapsus.

In Lusitania, the inscription FE 331 (=LLDB-40256) bears the text: Boutia[e] / Tangini f(iliae) / PROPTER / PALARVS QVADRATVS et [- - / - - - -, preserving a unique epigraphic expression - propter Palarum Quadratum - that might have the same meaning as would the standard pro salute Palari Quadrati. ${ }^{39}$ It seems reasonable to argue that this is

37 E.g. Plaut. Truc. 945: Tu uapula, uir strenuos. See Suárez Martínez (1994a: p. 121) and Adams (2013: p. 254).

38 The French translation provided in Conimbri (p. 158) is: 'Duatius, il vaudrait mieux que je me taise: ton fils te suce'. The vocative ending $-\bar{\imath}$ is correct for specific words like filius (whose variant filie is also attested - see Suárez Martínez 2017: p. 96) and is the only possible form for personal names of the second declension ending in -ius, such as Caecilius, Iulius, etc. Duatius is an indigenous name, of which the vocative form ending in $-e$ is probably attested in another graffito found in the same place (Conimbri 357a: Tolle me / [Du] ate).

See F. Patrício Curado et al. in FE 331. 
an example of an 'unconstrued nominative' or that the special character of the personal name has played a role in preserving it in the nominative. It is also of note that the inscription bearing the misspelling seems indeed to be a votive one, addressing some deity (the inscription is broken) in order to propitiate the health of the man mentioned in the formula.

On the other hand, the text IRCPacen 2 (= LLDB-17156) possibly records an hybrid spelling, combining a regular ablative with a nominative /genitive form: ...M(arcus) Acilius [Bal]/bus lib(ertus) [-- - / [- - P]RO SALVTE [ET RE/D]ITVS AEOR/VM] (!) / [a(nimo) $l($ ibens $)] / u($ otum $)[s($ oluit $)]$. If this reading is correct, it should be observed that the form reditu, regularly inflected, would have allowed the engraver to spare a letter (the letter $S$ ), conforming to stonemasons' common practice to use abbreviations and ligatures in order to save space on the stone. In contrast, the inflected form salute provides the semantic value of the complement (i.e. ablative), while reditus provokes a loss of agreement. Nonetheless, it remains an uncertain example because of the textual gap. ${ }^{40}$

\section{Accusative}

\subsection{Loss of Agreement}

A typical loss of agreement regarding the accusative occurs in expressions such as uixit annis... menses... dies..., where the indication of the subject's age is composed of an ablative varying into accusative, the inverse case being less frequent. ${ }^{41}$ Explanations of a different nature, mainly phonetic and morphological, have been offered for this phenomenon, ${ }^{42}$ while Suárez Martínez (1994b) pointed out that syntactic reasons - such as those presented above - may lie beneath it. ${ }^{43}$

In Lusitania, this situation is recorded in five examples, four of them starting with the ablative and then shifting into the accusative, ${ }^{44}$ and only one making the shift in the opposite direction: VIXIT COMMVNES ANNOS XXXXII MENSE I (IRCPacen 259 $=$ LLDB-41853). However, in this last case the loss of final $-m$ might explain the wrong spelling MENSE. There is another similar case, though very late (662 A.D.), where rea-

40 The formula pro salute is widely recorded also without et reditu. For this reason, the integration [P]RO SALVTE [ET RED]ITVS] is not completely secure, even if it is high probable (see e.g. AE 1988, 944, showing the same mistake). Alternatively, the form reditus might be the result of a contamination: see e.g. AE 1914, 217 ([pro] salute et uictoria et reditus Dominorum...) and CIL XI, 4082 (pro salute itus ac reditus D(omini) n(ostri) sanctissimi...).

41 The ablative case expressing time duration is attested in Classical literature (Bassols de Climent $1992^{10}$ : pp. 35 and 93-94) and is considered as the regular form in epigraphy (Suárez Martínez 1994b: p. 59).

42 It is generally claimed that the sequence $-i s \sim-e s \sim-e s$ is more euphonious than $-i s \sim-i b u s \sim-e b u s$, and that the ablative ending -bus was not popular. See Suárez Martínez (1994b: p. 57).

43 Suárez Martínez (1994b: p. 60).

44 IRCPacen 16 (= LLDB-41491): VIXIT ANNIS LII MENS(E) I DIES V; 83 (= LLDB-16371): VIX[IT] AN[N]IS [- - ] DIES [X]VIII; 346 (= LLDB-30103): VISSIT (!) ANNIS XIII DIES XV and FE 94 (= LLDB- 70194): VIXIT II ANO (!) VNO MENSE. 
sons of euphony cannot be claimed to explain the anomaly, whereas the conjunction of morpho-syntactical facts might be considered: VIXSIT (!) ANNOS L ET VNO for uixit annos quinquaginta et unum (CIPTP 109 = LLDB-29709). Confusions of the same type, showing a loss of agreement, are attested in other paleo-Christian epitaphs, such as CICMerida 24 (= LLDB-47926), where we read DEPOSITA EST DIAE (!) TERTIVM for deposita est die tertio.

On the epitaph IHC 2 (= LLDB-32774), the accusative appears instead in place of the ablative in a name-expression: Sinticio famulus D(e)i / cognomento DIDOMVM (!) paterno / traens (!) linea (!) Getarum..., where we would expect to read Deidomo.

In the verse inscription Badajoz 25 (= LLDB-30950), the verb renuntio ("withdraw from, renounce') is followed by a hybrid expression combining regular dative and accusative forms: Pascentius ama/tor Dei (...) renuntiauit M/VNDO PONPISQVE (!) LABEN/TIBVS EIVS FERALEMQVE / VITAM TEMVLENTIAQVE (!) PO/CVLA BACCHI... In this case, an expression from Virgil (Verg. Aen. 3, 354: pocula Bacchi) may have favoured the syntactic uariatio.

\subsection{Ungoverned Accusatives}

\subsubsection{Accusatiuus pro nominatiuo}

A mosaic inscription from Lusitania dated to the $4^{\text {th }}$ century A.D. bears the following sentence: Viuentes / Cardilium / et Auitam (!) / FELIX TVRRE (MosHispa SAN 1 = LLDB28604), where an accusative, $\operatorname{turre}(m)$, seems to be used instead of the nominative turris (although turre could also be an ablative).

Another similar example is found on a stone inscription of the $1^{\text {st }}$ century A.D.: [- - - - / h(ic) s(itus) est an(norum) / XXIIII / mater et FRATRE (posuerunt) (HEpOL-32544 = LLDB-60349). ${ }^{45}$ Yet this example is more uncertain, since the stone is broken and, apart from a missing $-m$ (fratrem), we could also think about a missing $-s$ (fratres). It might be even a case of transmutatio litterarum, i.e. a technical mistake (FRATRE for frater).

\subsubsection{Accusatiuus pro datiuo}

In our corpus, the accusative seems to replace the dative in the inscription FE 158 (= LLDB-39227): Val[erius] / Placed[us] (!) / exs (!) orti (!) [f]onte surp (!) DE/VM PO/SVIT, where we would expect to read deo posuit. However, this example is uncertain, for the correct reading might be super (or supra) deum posuit. ${ }^{46}$ In this case, we can imagine that a statue of the god stood above the altar - which is unfortunately broken - or that the altar itself was put above the spring mentioned in the text. ${ }^{47}$

45 Rivero de la Higuera (1970: pp. 345-346).

46 Nevertheless, the same reading SVRP is not secure. See J. L. Inês Vaz in FE 158 ('SNRP ou SVRP').

47 There is an altar from the province Pannonia Superior, which bears an image of the god Mithras and the text: super nasce[n]tem deum posuit (CIL III, 15184). 
Another possible example is the inscription CIL II, 427 (= LLDB-39234): Victor / Marii f(ilius) / heic (!) SE / p(osuit) iacet. The mistake SE P(OSVIT) for sibi posuit might depend on an analogy with the vulgar expression se uiuo posuit, ${ }^{48}$ or the word uiuo was accidentally omitted.

\subsubsection{Accusatiuus pro ablatiuo}

Just like the nominative, the accusative can appear instead of the ablative in absolute constructions, such as in IRCPacen 495 (= LLDB-29878): Deo / Endouellico / sacrum / M(arcus) Fannius / Augurinus / merito HVN[C] DEVM / SIBI PROPITIATVM, or in the already quoted inscription MosHispa SAN 1 (= LLDB-28603), which contains the syntagma VIVENTES CARDILIVM ET AVITAM for uiuentibus Cardilio et Auita. ${ }^{4}$

\subsubsection{Praepositio cum accusatiuo pro praepositione cum ablatiuo}

In Lusitania, the most frequent context where an accusative replaces another case, namely the ablative, is represented by prepositional clauses. Most of these examples are difficult to explain, for the instability of final $-m$ might lead to produce hypercorrected forms ${ }^{50}$ such as PRO PATREM for pro patre (CILCaceres I, 34 = LLDB-30985), or opposite examples, such as MITTERES ILLAM AT (!) TALE LABORE for mitteres illam ad talem laborem (Mallon p $550=$ LLDB-46326). Cases such as CVM CRATERA for cum crateris (IRCPacen 339 = LLDB-30102) are unequivocal.

\section{The Evolution of the Nominal Case System}

Analysis of the historical merging of the nominative and accusative with other grammatical cases can provide interesting information about the development of the Vulgar Latin nominal system. In fact, Adamik (2014) has observed that there is a correspondence between the overall view provided by the inscriptions and the Romance languages. Moreover, it is generally said that nouns passed into the Romance in their accusative form, not in the nominative, especially those referring to inanimate things. ${ }^{51}$

Charts referring to the general merging of cases in early and late Lusitania ${ }^{52}$ show effectively that the accusative tends to subsume the other forms over time $(13 \%>38 \%)$.

48 On this formula, see the paper of N. Zelenai in this volume.

49 See above, 3.2.1.

50 Galdi (2004: p. 443). See also Gaeng (1990: pp. 118-119).

51 Adams (2013: pp. 201-204); Velázquez Soriano (2004: p. 516). See e.g. lat. homo > it. uomo or lat. Carolus $>$ fr. Charles.

52 The graphics presented in this section have been created with data collected in LLDB on 11/01/2018. In order to provide a more realistic panorama of the nominal case system, I have excluded all phenomena labelled with one of the following alternative codes: archaismus (e.g. IRCPacen 647 = LLDB-29649: EXPERTEM PATRIA INCOLVMITATE FORTVNISQE OMNIBVS, for the use of expers with an ablative instead of 
This phenomenon is accompanied by a sharp increase of prepositional clauses replacing simple cases $(0 \%>13 \%),{ }^{53}$ as well as a total decrease of the opposite phenomenon $(8 \%$ $>0 \%$ ). According to the graphics, the nominative tends to be used as the base-form of names especially in early times $(17 \%>13 \%)$, while in late Lusitania this function is taken on by the accusative ( $13 \%$ vs $38 \%$ ).

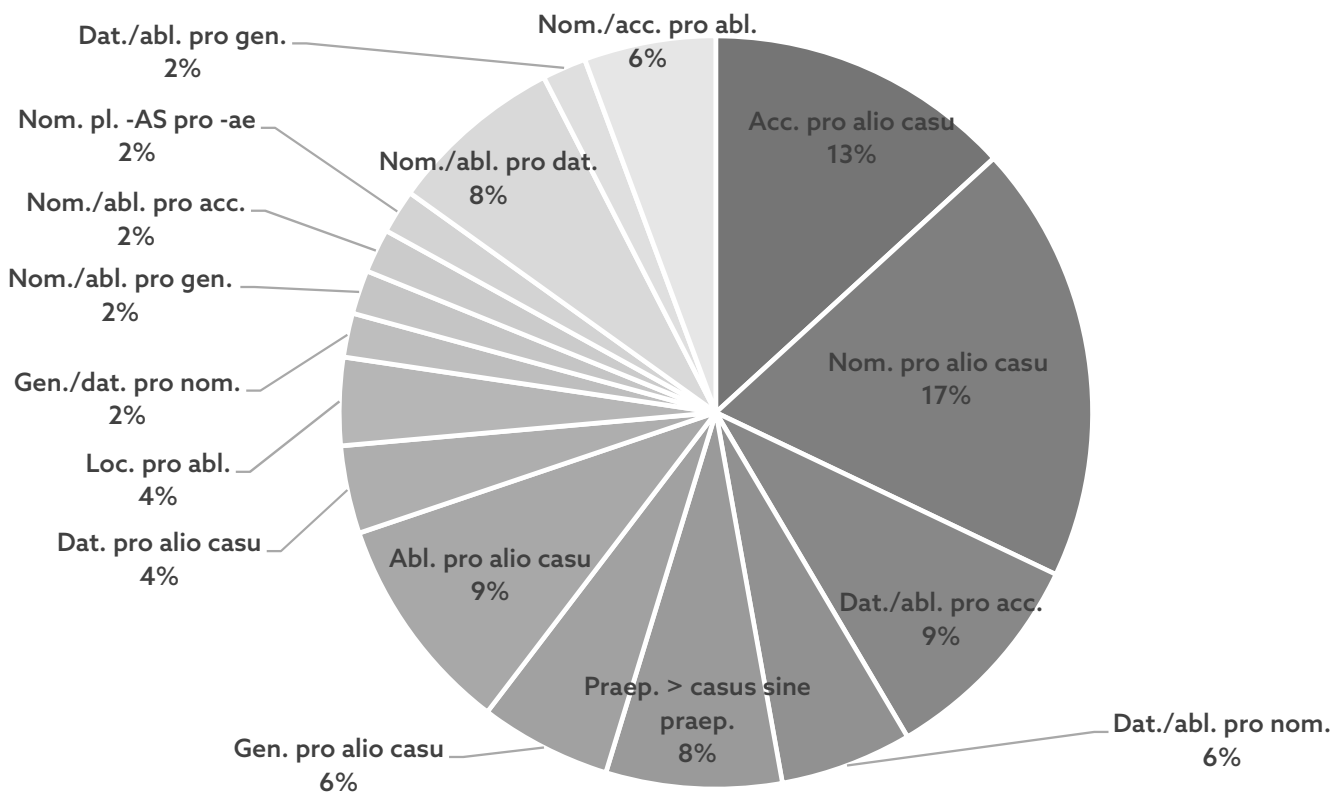

Chart 1: Case mergings in Early Lusitania ( $1^{\text {st }}-3^{\text {rd }}$ C. A.D.): $100 \%=53^{54}$

a genitive is mainly restricted to old Latin, see Martin 1909: p. 20); Graecismus (e.g. the formula TRIBVNICIAE POTESTATIS instead of tribunicia potestate, that is very likely a calque from the Greek $\delta \eta \mu \propto \rho \times\llcorner\mathrm{n} \tilde{S}$

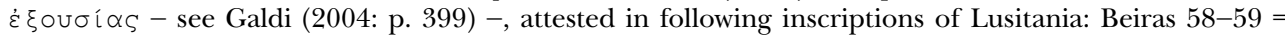
LLDB-44092; FE 102 = LLDB-44077; CIL II, 4636 = LLDB-44088 and CIL II, 4635 =LLDB-44089) and errores non grammatici (i.e. possible mistakes of a technical nature). By the same token, I have excluded all data labelled as 'fortasse recte' as well as those where the syntactic merge was not clearly discernible from morpho-phonological phenomena, such as the loss /addition of final consonants (e.g. CIL II, $6330=$ LLDB-60348: VOTVM QVO FECIT for uotum quod fecit).

53 The most common phenomenon in this framework is the use of SVB DIE instead of die (or, alternatively, ante diem), of which there are 27 examples in late Lusitania (CICMerida 5 = LLDB-38503, CIPTP $22=$ LLDB-29996, etc.). In order not to invalidate Chart 2, I have considered only one item of this type.

54 Nom. pro alio casu: LLDB-16400 (IRCPacen 430); 17383 (IRCPacen 186); 28858 (Conimbri 357b); 28865 (Conimbri 11); 32090 (IRCPacen 52); 34424 (ERAEmerita 146); 35104 (HEp 4, 166); 36789 (ERBeira 206); 40256 (FE 331); 70892 (CILCaceres II, 668); acc. pro alio casu: LLDB-28865 (Conimbri 11); 29878 (IRCPacen 495); 29887 (IRCPacen 523); 30102 (IRCPacen 339); 39234 (CIL II, 427); 41853 (IRCPacen 259); 47758 (HEp 14, 32); abl. pro alio casu: LLDB-30094 (IRCPacen 316); 36134 (ERAEmerita 124); 41853 (IRCPacen 259); 46338 (MiliariosPlata 182); 60483 (Conimbri 71); dat. / abl. pro acc.: LLDB-17314 (IRCPacen 143); 32327 (ERAEmerita 293); 44106 (FE 360); 45891 (Mallon p 550); 46311 (IRPToledo 149); nom. / abl. pro dat.: LLDB-15484 (CILCaceres II, 668); 15590 (CILCaceres III, 1140); 25562 (CILCaceres II, 631 ); 32226 


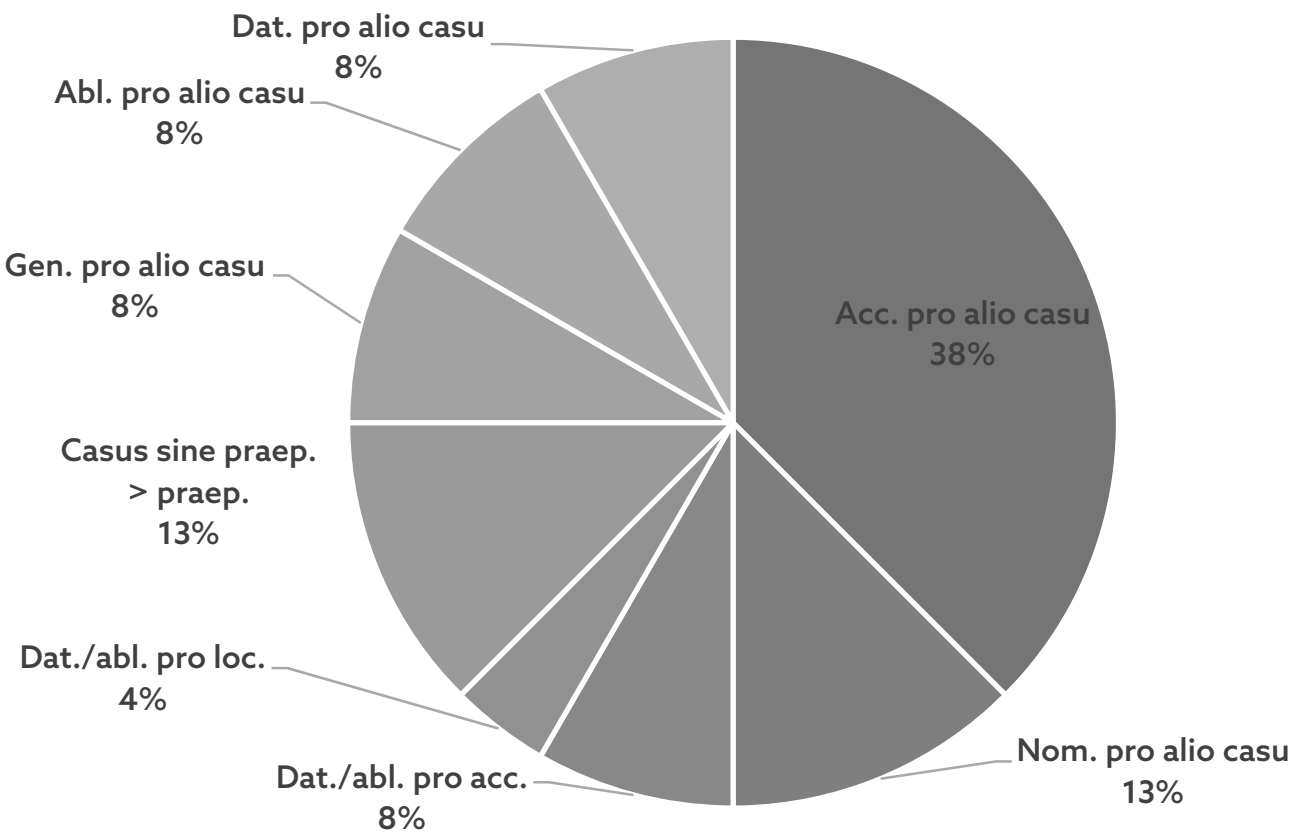

Chart 2: Case mergings in Late Lusitania $\left(4^{\text {th }}-8^{\text {th }}\right.$ C. A.D. $): 100 \%=24^{55}$

In the Visigoth Slates ${ }^{56}$ - the data of which I have omitted from Chart 2 for methodological reasons - 'the distinction between the nominative and the accusative disappears not only on the functional but also on the morphological level' ${ }^{57}$ Indeed, in the second declension, accusatives ending $-u(m)$ tend to replace masculine nominatives ending $-u(s)$, in the same way as $-a /-a(m)$ clearly alternate in feminine nouns. ${ }^{58}$ This phenomenon is

(CivIgaed 172); praep. > casus sine praep.: LLDB-29514 (IRCPacen 412); 36134 (ERAEmerita 124); 58870 (ERAEmerita 407); 60437 (IRCPacen 143); dat. / abl. pro nom.: LLDB-72630 (FE 366); 16959 (IRCPacen 16); 59338 (HEp 7, 1273); gen. pro alio casu: LLDB-28683 (CIL II, 347); 44105 (FE 360); 60054 (Badajoz 51); nom. / acc. pro abl.: LLDB-30103 (IRCPacen 346); 16371 (IRCPacen 83); 41491 (IRCPacen 16); dat. pro alio casu: LLDB-60322 (Scallabis 20); 60702 (ERAEmerita 394); dat. / abl. pro gen.: LLDB-28828 (HEp 6, 1049); gen. / dat. pro nom.: LLDB-32226 (CivIgaed 172); loc. pro abl.: LLDB-28683 (CIL II, 347); 60054 (Badajoz 51); nom. / abl. pro acc.: LLDB-15484 (CILCaceres II, 668); nom. / abl. pro gen.: LLDB-44080 (HEp 7, 1273); nom. -AS pro -ae: LLDB-16388 (IRCPacen 331).

55 Acc. pro alio casu: LLDB-28604 (MosHispa SAN 1); 30950 (Badajoz 25); 32774 (IHC 2); $36687 / 36688$ (CICMerida 29); 47926 (CICMerida 24); 59567 (IHC 11); 64424 (CIPTP 161); 70194 (FE 94); nom. pro alio casu: LLDB-32788 (CICMerida 20); 45725 (CILCaceres III, 923); 60213 (CILCaceres IV, 1159); casus sine praep. > praep. (except SVB DIE for die / ante diem, see above, n. 53): LLDB-32786 (CICMerida 20); 28309 (Olisipo 22); abl. pro alio casu: LLDB-28604 (MosHispa SAN 1); 59567 (IHC 11); dat. pro alio casu: LLDB-36682 (CICMerida 29); 69270 (IHC 2); dat. / abl. pro acc.: LLDB-29709 (CIPTP 109); 29733 (FE 94); gen. pro alio casu: LLDB-29855 (CIPTP 124) ; 31779 (CIPTP 161); dat. / abl. pro loc.: LLDB-60380 (Badajoz 15).

56 Which date from approximately the $5^{\text {th }}$ through to $7^{\text {th }}$ century A.D.

57 Herman (2006 [1995]: p. 28): 'La distinction entre nominatif et accusatif se perd sur le plan fonctionel comme sur le plan morphologique'.

Herman (2006 [1995]: p. 27). 
accompanied by the morphological merging between -os and $-i$ in the masculine plural, which, according to Herman, represents a reaction to the widespread use of feminine forms ending in $-a s .{ }^{59}$ Herman goes on to state that 'the nominal paradigm does not distinguish the nominative from the accusative, nor from the other oblique cases, anymore' ${ }^{60}$ In contrast, according to Adams, 'there is no reason to think that the -os forms would have been regarded as alternative nominative forms' in the Visigoth Slates, where many list constructions are attested, 'because lists (...) traditionally show variations between nominative and accusative'. ${ }^{61}$ He suggests that the standardization of accusative forms is a very late phenomenon (possibly only medieval), but admits that in earlier times 'the accusative was sometimes entering the territory of the nominative and other cases ad hoc, in different constructions and with different determinants' ${ }^{62}$

Consequently, the overview provided by our data seems to reflect an initial trend towards the future development of a one-case system, which is typical of the Ibero-Romance languages, where the nominative and the accusative merged, the latter of which overlapping not only the former but also all other cases. ${ }^{63}$

\section{Conclusions}

Several abnormal uses of the nominative as well as the accusative case are attested in the epigraphic corpus of Lusitania, both in early and in later times. Besides common errors which cause a loss of agreement between mixed inflected and uninflected forms - the dialectological value of which might be questioned,$-{ }^{64}$ anomalies in the case government suggest that there was a trend to deploy the nominative and the accusative as neutral forms in substitution for other semantic values. Over the centuries, the encroaching of the accusative on the other cases, including the nominative, became progressively widespread, until the creation of a mono-casual nominal system, which in due course appeared in the later Ibero-Romance languages.

59 Herman (2006 [1995]: p. 27); see also Velázquez Soriano (2004: p. 515). On the nominative ending plural -as, see also Gaeng (1977: pp. 47-51; 1984: pp. 19-22; 1990: pp. 114-115).

60 Herman (2006 [1995]: p. 29): 'Le paradigme nominal ne distingue plus le nominatif de l'accusative, ni des autres cas obliques'. See also Bassols de Climent $\left(1992^{10}\right.$ : p. 40): 'En latín tardío, y más concretamente en inscripciones hispánicas, reaparece este uso (scil. nom. -as for -ae), que probablemente responde a la tendencia a usar el acusativo en función de nominativo'.

61 Adams (2013: p. 231).

62 Adams (2013: p. 234).

63 Adamik (2014: p. 658).

64 Adams (2013: p. 207). See Herman (1990 [1966]). 


\section{Bibliography}

Adamik, B. (2014). In Search of the Regional Diversification of Latin: Changes of the Declension System according to the Inscriptions. In P. Molinelli et al. (Eds.), Latin vulgaire - Latin tardif X. Actes du $X^{e}$ Colloque International sur le Latin vulgaire et tardif. Bergamo, 5-9 septembre 2012 (pp. 641-661). Bergamo: Bergamo University Press.

Adamik, B. (2017). The Problem of the Omission of Word-final $-s$ as Evidenced in Latin Inscriptions. Graeco-Latina Brunensia, 22(2), 5-22.

Adams, J. N. (2013). Social Variation and the Latin Language. Cambridge: Cambridge University Press.

Bassols de Climent, M. $\left(1992^{10}\right)$. Sintaxis latina. Madrid: Consejo Superior de Investigaciones Científicas.

Batlle Huguet, P. (1963). Epigrafía latina. Barcelona: Escuela de Filología.

Beu-Dachin, E. (2014). The Latin Language in the Inscriptions of Roman Dacia. Cluj-Napoca: MEGA Publishing House.

Burkard, T., \& Schauer, M. (20125). Lehrbuch der lateinischen Syntax und Semantik. Darmstadt: Wissenschaftliche Buchgesellschaft.

Carnoy, A. $\left(1906^{2}\right)$. Le latin d'Espagne d'après les inscriptions. Etude linguistique. Bruxelles: Misch \& Thron.

Gaeng, P. (1977). A Study of Nominal Inflection in Latin Inscriptions. A Morpho-Syntactic Analysis (North Carolina Studies in the Romance Languages and Literatures, 182). Chapel Hill: University of North Carolina Press.

Gaeng, P. (1984). Collapse and Reorganisation of the Latin Nominal Flection as Reflected in Epigraphic Sources. Potomac: Scripta Humanistica.

Gaeng, P. (1990). La flexion nominale à l'époque du latin tardif: essai de reconstruction. In G. Calboli (Ed.), Latin vulgaire - Latin tardif II. Actes du IIème Colloque international sur le latin vulgaire et tardif (Bologne, 29 août - 2 septembre 1988) (pp. 111-128). Tübingen: Niemeyer.

Galdi, G. (2004). Grammatica delle iscrizioni latine dell'Impero (province orientali): morfosintassi nominale. Roma: Herder Editrice.

Herman, J. (1990 [1966]). Recherches sur l'évolution grammaticale du latin vulgaire: les emplois «fautifs» du nominative. In S. Kiss (Ed.), József Herman. Du latin aux langues romanes. Études de linguistique historique (pp. 321-325). Tübingen: Niemeyer [= Acta classica Universitatis scientiarum debreceniensis, 2, 1966, 109-112].

Herman, J. (2006 [1995]). Les ardoises wisigothiques et le problème de la différentiation territoriales du latin. In S. Kiss (Ed.), József Herman. Du latin aux langues romanes II. Nouvelles études de linguistique historique (pp. 19-30). Tübingen: Niemeyer [= Latin vulgaire - Latin tardif, Hildesheim: Olms-Weidmann, pp. 63-76].

Hofmann, J. B., \& Szantyr, A. (1965). Lateinische Syntax und Stilistik. München: Beck.

Marchesini, S. (2004). Excursus metodologico sugli errori di scrittura. Analisi di un corpus epigrafico dell'Italia antica. Studi Classici e Orientali, 50, 173-230.

Martin, H. (1909). Notes on the Syntax of the Latin Inscriptions Found in Spain. Baltimore: J. H. Furst Company.

Moralejo, J. L. (1986). Sobre los casos latinos. Revista de la Sociedad Española de Lingüistica, 16, 293-323. 
Poukens, J. B. (1912). Syntaxe des inscriptions latines d'Afrique. Le Musée Belge. Revue de Philologie Classique, 16.

Rivero de la Higuera, M. C. (1970). La villa romana de Leoncillo, su cipo funerario y la inscripción de Berry (Badajoz). Zephyrus, 21, 329-347.

Suárez Martínez, P. M. (1994a). El nominativo latino: funciones sintácticas y funciones de lenguaje. Anuari de Filologia, 17, 115-123.

Suárez Martínez, P. M. (1994b). Vixit annis XXX menses III dies XIX. In J. Herman (Ed.), Linguistic Studies on Latin. Selected Papers from the 6th International Colloquium on Latin Linguistics (Budapest, 23-27 March 1991) (pp. 55-63). Amsterdam - Philadelphia: Benjamins.

Suárez Martínez, P. M. (1998). Función cero en la sintaxis casual latina. In B. García Hernández et al. (Eds.), Estudios de lingüistica latina. Actas del IX Coloquio Internacional de Lingüistica Latina: Universidad Autónoma de Madrid, 14-18 de abril de 1997 (pp. 781-790). Madrid: Ediciones Clásicas.

Suárez Martínez, P. M. (1999). El valor de los casos en los sintagmas preposicionales latinos. Faventia, 21(2), 65-74.

Suárez Martínez, P. M. (2017). Le vocatif en $-\imath ̄$ de la deuxième déclination latine. Pallas, 103, 95-102.

Urbanová, D. (f.c.). Between Syntax and Magic - Some Peculiarities of Nominal Syntax in Latin Curse Tablets. Proceedings of the XIX International Colloquium on Latin Linguistics, München, 24-28 April 2017.

Velázquez Soriano, I. (2004). Las pizarras visigodas. Entre el latín y su disgregación: la lengua hablada en Hispania, siglos VI-VIII (Colección Beltenebros, 8). Burgos: Fundación Instituto Castellano y Leonés de la Lengua.

Silvia Tantimonaco / silvia.tantimonaco@gmail.com

Research Group LITTERA (2017SGR241)

University of Barcelona

Gran Via de les Corts Catalanes 585, 08007 Barcelona, Spain 
